were from International Tables for X-ray Crystallography (1974, Vol. IV). The PARST program (Nardelli, 1983) was used for molecular geometry calculations. The atomic parameters are given in Table $1 .^{*}$ The bond lengths, valence angles and geometrical parameters of selected intermolecular interactions are given in Table 2 . A perspective view of the title compound is given in Fig. 1. The crystal packing along the $a$ axis is shown in Fig. 2 .

Related literature. The geometry at $\mathrm{S}(1)$ conforms to that found for related $p$-tolylsulfinyl derivatives (de la Camp \& Hope, 1970; Hua, Badejo, McCann \& Takusagawa, 1987). In the epoxidic ring the $\mathrm{C}(2)$ $O(1)$ and $C(3)-O(1)$ bond lengths of $1.453(8)$ and 1.435 (9) $\AA$, respectively, are close to the accepted value of $1.446(14) \AA$ for $\mathrm{C}\left(s p^{3}\right)-\mathrm{O}$ bonds in epoxides with any substitution (Allen, Kennard,

* Lists of structure factors, anisotropic thermal parameters and $\mathrm{H}$-atom parameters have been deposited with the British Library Document Supply Centre as Supplementary Publication No. SUP 54857 ( 7 pp.). Copies may be obtained through The Technical Editor, International Union of Crystallography, 5 Abbey Square, Chester CH1 2HU, England. [CIF reference: GE0292]
Watson, Brammer, Orpen \& Taylor, 1987). In the structure two short contacts, $\mathrm{C}-\mathrm{H} \cdots \mathrm{O}$ and $\mathrm{C}-\mathrm{H} \cdots \mathrm{F}$, exist, which can be reasonably described as hydrogen bonds (Taylor \& Kennard, 1982).

We thank Professor G. Cavicchio of Università dell'Aquila, for providing a sample of the title compound.

\section{References}

Allen, F. H., Kennard, O., Watson, D. G., Brammer, L., OrPen, A. G. \& TAyloR, R. (1987). J. Chem. Soc. Perkin Trans. 2, pp. S1-S19.

Bravo, P. \& Resnati, G. (1990). Tetrahedron Asymm. 1, 661-692. CAMP, U. DE LA \& Hope, H. (1970). Acta Cryst. B26, 846-853.

Cavicchio, G., Bravo, P., Marchetti, V. \& Zappalá, C. (1991). Tetrahedron Asymm. In preparation.

Cavicchio, G., Marchetti, V., Arnone, A., Bravo, P. \& Viant, F. (1990). Gazz. Chim. Ital. 120, 821-822.

Hua, D. H., Badejo, I., McCann, P. J. \& Takusagawa, F. (1987). Acta Cryst. C43, 1112-1114.

NARDElli, M. (1983). Comput. Chem. 7, 95-98.

SHELDRICK, G. M. (1990). SHELXTL-Plus. Release 4.1 for Siemens $R 3 \mathrm{~m} / V$ crystallographic system. Siemens Analytical $\mathrm{X}$-ray Instruments, Inc., Madison, Wisconsin, USA.

TaYlor, R. \& KenNard, O. (1982). J. Am. Chem. Soc. 104, 5063-5070.

Acta Cryst. (1992). C48, 1133-1134

\title{
Structure of 4,6-Diacetylresorcinol
}

\author{
By M. K. Kokila, K. A. Nirmala and Puttaraja \\ Department of Physics, Bangalore University, Bangalore-560 056, India \\ AND N. Shamala \\ Department of Physics, Indian institute of Science, Bangalore-560 012, India
}

(Received 12 January 1991; accepted 24 October 1991)

\begin{abstract}
C}_{10} \mathrm{H}_{10} \mathrm{O}_{4}, M_{r}=194.19$, monoclinic, $P 2_{1} / c$, $a=7.089$ (1), $b=11.361$ (1), $c=11.656$ (1) $\AA, \beta=$ $100.45(3)^{\circ}, V=922.92(1) \AA^{3}, Z=4, D_{m}=1.410(5)$, $D_{x}=1.397 \mathrm{Mg} \mathrm{m}^{-3}, \quad \lambda(\mathrm{Cu} K \alpha)=1.5418 \AA$, $\mu(\mathrm{Cu} \mathrm{K \alpha})=0.89 \mathrm{~mm}^{-1}, \quad T=300 \mathrm{~K}, \quad F(000)=408$, final $R=0.057$ for 1701 observed reflections. The molecule is almost planar, with $\mathrm{O}(9)$ and $\mathrm{O}(12)$ of the acetyl groups deviating by $0.074(1)$ and 0.071 (2) $\AA$ from the mean plane of the benzene ring. The bond lengths and bond angles of the benzene ring are normal. There are intramolecular hydrogen bonds between $\mathrm{O}(9)$ and $\mathrm{H}(14)$ and between $\mathrm{O}(12)$ and $\mathrm{H}(13)$; there are no intermolecular hydrogen
\end{abstract}

0108-2701/92/061133-02\$06.00 bonds. The molecules are packed in layers parallel to the $a c$ plane and are held together essentially by van der Waals interactions.

Experimental. The title compound is obtained by the reaction of acetic anhydride and resorcinol in the presence of $\mathrm{ZnCl}_{2}$; crystals suitable for X-ray analysis were grown in benzene solution by slow evaporation; orange crystal $0.3 \times 0.4 \times 0.2 \mathrm{~mm}$ mounted on an Enraf-Nonius CAD- 4 diffractometer, $\omega / 2 \theta$ scan; cell dimensions from least-squares refinement of 25 reflections in the $2 \theta$ range 0 to $55^{\circ}$; density measurements by flotation technique using potassium iodide

(C) 1992 International Union of Crystallography 
Table 1. Fractional coordinates $\left(\times 10^{4}\right)$ and equivalent isotropic temperature factors $\left(\AA^{2} \times 10^{4}\right)$ for non- $\mathrm{H}$ atoms; e.s.d.'s are given in parentheses

\begin{tabular}{lccrc}
\multicolumn{5}{c}{$U_{\text {eq }}=(1 / 3) \sum_{i} \sum_{j} U_{i j} a_{i}^{*} a_{j}^{*} \mathbf{a}_{i} \cdot \mathbf{a}_{j}}$. \\
C(1) & $x$ & $y$ & $z$ & $U_{\text {eq }}$ \\
$\mathrm{C}(2)$ & $3057(2)$ & $6414(1)$ & $35(1)$ & $433(5)$ \\
$\mathrm{C}(3)$ & $2310(2)$ & $6121(1)$ & $-1113(1)$ & $480(6)$ \\
$\mathrm{C}(4)$ & $1750(2)$ & $4981(1)$ & $-1393(1)$ & $441(5)$ \\
$\mathrm{C}(5)$ & $1900(2)$ & $4095(1)$ & $-517(1)$ & $405(5)$ \\
$\mathrm{C}(6)$ & $2618(2)$ & $4418(1)$ & $629(1)$ & $395(5)$ \\
$\mathrm{C}(7)$ & $3207(2)$ & $5564(1)$ & $935(1)$ & $402(5)$ \\
$\mathrm{C}(8)$ & $4003(2)$ & $5890(1)$ & $2144(1)$ & $483(5)$ \\
$\mathrm{O}(9)$ & $4111(4)$ & $5019(2)$ & $3107(2)$ & $654(7)$ \\
$\mathrm{C}(10)$ & $4586(2)$ & $6904(1)$ & $2374(1)$ & $641(5)$ \\
$\mathrm{C}(11)$ & $1315(2)$ & $2881(1)$ & $-838(1)$ & $478(5)$ \\
$\mathrm{O}(12)$ & $1426(3)$ & $1949(2)$ & $75(2)$ & $594(7)$ \\
$\mathrm{O}(13)$ & $727(3)$ & $2619(1)$ & $-1865(1)$ & $720(6)$ \\
$\mathrm{O}(14)$ & $1067(2)$ & $4726(1)$ & $-2517(1)$ & $642(5)$ \\
& $3612(2)$ & $7534(1)$ & $269(1)$ & $611(5)$
\end{tabular}

solution; intensity data collected using $\mathrm{Cu} K \alpha$ radiation to a maximum $\theta=75^{\circ}$; three standard reflections $(1 \overline{2} \overline{1}, \overline{1} 02,2 \overline{1} \overline{2})$ monitored after every 50 reflections; $h,-8$ to $8, k, 0$ to $14, l, 0$ to 13 ; total of 3850 reflections of which 1853 were unique $\left(R_{\mathrm{int}}=\right.$ $0.019) ; 1701$ reflections with $I \geq 3 \sigma(I)$ were considered observed; data corrected for Lorentzpolarization effects. The structure was solved using MULTAN84 (Main, Germain \& Woolfson, 1984) and DIRDIF (Beurskens, Bosman, Doesberg, Van den Hark, Prick, Noordik, Beurskens, Gould \& Parthasarathy, 1984); all the $\mathrm{H}$ atoms were located from difference Fourier maps; full-matrix leastsquares refinement with anisotropic thermal parameters for non- $\mathrm{H}$ atoms and isotropic thermal parameters for $\mathrm{H}$ atoms using $S H E L X 76$ (Sheldrick, 1976); 167 parameters refined and 10 reflections per parameter; final $R=0.0570$ and $w R=0.0781, w=\left[\sigma^{2}(F)+\right.$ $\left.g F^{2}\right]^{-1}, g=0.0011, \sigma$ 's based on counting statistics; the refinement terminated when shift/e.s.d.'s for non- $\mathrm{H}$ atoms was less than 0.1 ; the minimum and maximum residual electron densities in the final difference Fourier map were -0.10 and 0.11 e $\AA^{-3}$, respectively. The final positional parameters of the non-H atoms with $U_{\text {eq }}$ are given in Table $1 .^{*}$ The ORTEP (Johnson, 1965) plot of the molecule with $50 \%$ probability ellipsoids is shown in Fig. 1; the bond lengths, bond angles and hydrogen-bonding parameters are given in Table 2.

The authors wish to thank Professor M. A. Viswamitra, Department of Physics, IIsc, Bangalore, India, for the data and also for providing facilities to solve

\footnotetext{
* Lists of structure factors, anisotropic thermal parameters and $\mathrm{H}$-atom parameters have been deposited with the British Library Document Supply Centre as Supplementary Publication No. SUP 54802 (11 pp.). Copies may be obtained through The Technical Editor, International Union of Crystallography, 5 Abbey Square, Chester CHI 2HU, England.
}

Table 2. Bond lengths $(\AA)$, bond angles $\left({ }^{\circ}\right)$ and hydrogen-bonding parameters; e.s.d.'s are in parentheses

\begin{tabular}{|c|c|c|c|c|}
\hline$C(1)-C(2)$ & $1.387(2)$ & \multicolumn{2}{|c|}{$C(5)-C(6)$} & $1.394(2)$ \\
\hline$C(1)-C(6)$ & $1.416(2)$ & \multicolumn{2}{|c|}{$C(6)-C(7)$} & $1.467(2)$ \\
\hline$C(1)-O(14)$ & $1.345(2)$ & \multicolumn{2}{|c|}{$C(7)-C(8)$} & $1.487(3)$ \\
\hline$C(2)-C(3)$ & $1.376(2)$ & \multicolumn{2}{|c|}{$C(7)-O(9)$} & $1.238(2)$ \\
\hline$C(3)-C(4)$ & $1.425(2)$ & \multicolumn{2}{|c|}{$C(10)-C(11)$} & $1.493(2)$ \\
\hline$C(3)-O(13)$ & $1.343(2)$ & \multirow{2}{*}{\multicolumn{2}{|c|}{$\mathrm{C}(10)-\mathrm{O}(12)$}} & $1.230(2)$ \\
\hline$C(4)-C(5)$ & 1.389 (2) & & & \\
\hline$C(4)-C(10)$ & $1.469(2)$ & & & \\
\hline$C(6)-C(1)-C(2)$ & $121.1(1)$ & \multicolumn{2}{|c|}{$\mathrm{C}$} & 121. \\
\hline$O(14)-C(1)-C(2)$ & 118.0 & \multicolumn{2}{|c|}{$C(8)-C(7)-C(6)$} & $121.0(2)$ \\
\hline$O(14)-C(1)-C(6)$ & $120.9(1)$ & \multicolumn{2}{|c|}{$O(9)-C(7)-C(6)$} & $119.8(2)$ \\
\hline$C(3)-C(2)-C(1)$ & $119.9(1)$ & \multicolumn{2}{|c|}{$\mathrm{O}(9)-\mathrm{C}(7)-\mathrm{C}(8)$} & $119.1(2)$ \\
\hline$C(4)-C(3)-C(2)$ & $120.9(1)$ & \multirow{2}{*}{\multicolumn{2}{|c|}{$C(11)-C(10)-C(4)$}} & $118.2(2)$ \\
\hline$O(13)-C(3)-C(4)$ & $120.9(2)$ & & & $120.5(1)$ \\
\hline$C(5)-C(4)-C(3)$ & $118.0(1)$ & \multicolumn{2}{|c|}{$O(12)-C(10)-C(4)$} & $120.3(2)$ \\
\hline$C(10)-C(4)-C(3)$ & $120.0(1)$ & \multirow{2}{*}{\multicolumn{2}{|c|}{$\mathrm{O}(12)-\mathrm{C}(10)-\mathrm{C}(11)$}} & ) $119.2(2)$ \\
\hline$C(10)-C(4)-C(5)$ & $122.0(1)$ & \multirow{2}{*}{\multicolumn{2}{|c|}{$\begin{array}{l}C(6)-C(5)-C(4) \\
C(7)-C(6)-C(1)\end{array}$}} & $122.3(1)$ \\
\hline$C(5)-C(6)-C(1)$ & $117.9(1)$ & & & 120.3( \\
\hline$x-$ & $\underset{(\AA)}{X-\mathrm{H}}$ & $\begin{array}{c}\mathrm{H} \cdots Y \\
(\AA)\end{array}$ & $\begin{array}{c}X \cdots Y \\
(\AA)\end{array}$ & $\underset{\left({ }^{\circ}\right)}{X-\mathrm{H} \cdots Y}$ \\
\hline$O(14)-H(14) \cdot$ & $1.055(29)$ & $1.534(30)$ & 2.528 & $155(3)$ \\
\hline $\mathrm{O}(13)-\mathrm{H}(13) \cdots \mathrm{O}(12$ & 2) $0.959(34)$ & $1.644(33)$ & 2.536 & $153(3)$ \\
\hline
\end{tabular}

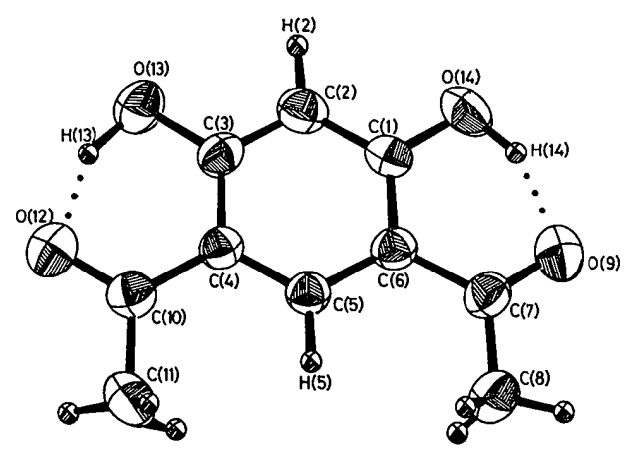

Fig. 1. A perspective view of the molecule with $50 \%$ probability thermal ellipsoids.

the structure. They also thank Dr V. R. Venkataraman, Professor of Chemistry, Jamal Mohamed College, Tiruchirapalli-620 020 , for providing the crystals and Dr M. V. Kulkarni, Department of Chemistry, Central College, Bangalore-560 001, for useful discussions.

\section{References}

Beurskens, P. T., Bosman, W. P., Doesberg, H. M., Van den Hark, Th. E. M., Prick, P. A. J., NoOrdik, J. H., Beurskens, G., Gould, R. O. \& ParThasarthy, V. (1984). DIRDIF. Tech. Rep. 1984/1. Crystallography Laboratory, Toernooiveld, 6525 ED Nijmegen, The Netherlands.

JoHNSON, C. K. (1965). ORTEP. Report ORNL-3794. Oak Ridge National Laboratory, Tennessee, USA.

Main, P., Germain, G. \& Woolfson, M. M. (1984) MULTAN84. A System of Computer Programs for the Automatic Solution of Crystal Structures from X-ray Diffraction Data. Univ. of York, England.

SHELDRICK, G. M. (1976). SHELX76. Program for crystal structure determination. Univ. of Cambridge, England. 